\title{
視対象のある部屋のビジビリティに基づく形状最適化 SHAPE OPTIMIZATION OF ROOMS WITH A VISUAL TARGET TO MAXIMIZE ITS VISIBILITY
}

\author{
本間 健太郎*1, 今井 公太郎*2 \\ Kentaro HONMA and Kotaro IMAI
}

\begin{abstract}
We research theoretically about optimal shapes of rooms such as classrooms with a blackboard, theaters with a stage, and galleries with a painting. (i) A reasonable formula "point-visibility" is proposed from an arbitrary viewpoint, introducing angle-resistance $\alpha$ and distance-resistance B. (ii) As aggregation of the point-visibility "area visibility" is proposed, introducing inequality $p$. (iii) The optimal room shape to maximize its areavisibility is derived. In conclusion, by determining " $\alpha$ and $B$ representing human eyesight" and " $p$ depending on rooms' usage", we can immediately acquire the optimal room shape.
\end{abstract}

Keywords : Visibility, Room shape optimization, Equality, Distance-resistance, Angle-resistance, Solid angle ビジビリティ, 部屋形状最邅化, 公平性, 距離抵抗, 角度抵抗, 立体角

\section{1.はじめに}

本論の目的は，部屋の形状を「ビジビリティ」(部屋内にある視対 象の見やすさ）という観点から評価し，それに基づき最適な部屋形 状を求めることである。想定する視対象は, 教室における黒板や教 師, 劇場におけるステージ, 展示室における絵画など多岐にわたる が，その見やすさが部屋形状に影響をおよぼすほど重要だという共 通点がある。それら視対象を見やすくさせる部屋の形状について, 計画上設計上の指針を得るために，統一的かつ演繹的に論を展開す る。具体的には，(i)まず任意の視点からの「ビジビリティ」を表す 妥当な関数を提案する ( 4 章)。その提案式は, 直観的に理解できて 操作的であるだけでなく, 視対象を見込む立体角の近似式を広く一 般化したものだと示される。(ii)次にビジビリティの妥当な集計方法 を提案し，視点を点から面に拡げたときの部屋形状の評価值「エリ アビジビリティ」を導出する ( 6 章)。エリアビジビリティは, 見づ らい場所を減らすべき用途（着席した生徒間の公平性を高めたい教 室など）も，見や寸い場所を増やす心゙き用途（鑑賞者が鑑賞位置を 決められる展示室など) も, 包括的に評価できる表現になっている。 (iii)最後にエリアビジビリティを最大化する, 最適な部屋の形状を 導出する ( 8 章)。ここでは面積を所与とする長方形プランの部屋に おいて, ひとつの壁の中央に視対象を設置したときの, 最適な部屋 の幅と奥行を求めている。

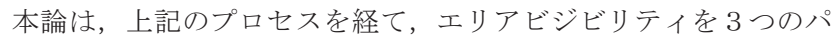
ラメータを含む形で明確に書き下し, パラメータと最適部屋形状の 関係を明らかにする。この 3 パラメータのうち 2 つは, ビジビリテ イ関数に由来するもので, 視対象を斜めに見ることの負の影響度 $\alpha$ と, 視対象から遠ざかることの負の影響度 $\beta$ である。残りの 1 つの パラメータは, ビジビリティの集計時に導入するもので，ビジビリ
ティ分布の不公平度 $p$ である。まとめると, $\Gamma \alpha$ と $\beta$ で表される人間 の視認感覚や視対象の性質」と「 $p$ で表される部屋の使い方や社会 の通念」を,「エリアビジビリティという部屋形状の評価值」ひいて は「部屋の最適形状」に直結できるのである。つまり前提条件を決 めるとプランニングに役立つ情報が直ちに求まるわけで，従来経験 的に行われがちであったビジビリティ評価を客観的に行うための基 礎知見として有用だと考えている。

\section{2. 本研究の位置づけ}

建築計画・都市計画分野におけるビジビリティの研究は数多く, なかでも外部空間を対象としたものが多い。例えば天空や建築物や 並木の見え方について，実測・実験・アンケート・シミュレーショ ン寸る研究が見られる。これらの大半は調査ベースの研究であるが, 理論ベースの研究として, 平澤ら ${ }^{1)}$ は, 並木の立体角を定式化し, 歩 行者が移動する際の緑視率の変化を計算している。これに対し本論 は，時間変化を扱わない代わりに，線（移動ルート）でなく面（視 点が存在する領域）の評価值を議論するものである。

内部空間については，展示室における絵画のビジビリティについ ての研究がいくつかある。平林ら ${ }^{2)}$ は, 鑑賞者から絵画までの距離と 角度にもとづくビジビリティ分布を定式化し, 被験者実験により得 られた鑑賞位置の選好順序を再現するような分布パラメータを推定 している。ビジビリティの空間分布を考えている点が同じであるが， 本論はそれを用いて部屋形状の評価と最適化を行うところに独自性 がある。

また本論は広範な対象を一括して議論する。これに対し，より直 接的なアプローチとして, 設計案の個別検討の手段としてビジビリ ティ解析を用いる立場がある。佐藤ら ${ }^{3)}$ は, 劇場の各座席からみた舞
*1 東京大学生産技術研究所 准教授 - 博士 (工学)

*2 東京大学生産技術研究所 教授·博士 (工学)
Assoc. Prof., Inst. of Industrial Science, The Univ. of Tokyo, Dr.Eng.

Prof., Inst. of Industrial Science, The Univ. of Tokyo, Dr.Eng. 
台の可視率を, 手寸りや他の観客までも考慮した緻密なシミュレー ションにより計算し, 複数プランの比較を行っている。

また本論で行うことを数学的に表現すると, (a)点（視対象の代表 点）と (b)長方形領域に一様分布する点（部屋内の視点）の間の $\underline{(\mathrm{c}) \text { 角 }}$ 度つき距離の幕乗（ビジビリティ）を面積分することになる。これ は解析的に取り扱うのが難しい問題である。これに関係して栗田 ${ }^{4)}$

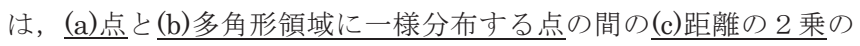
平均を求めている。さらにこれを一般化して栗田 ${ }^{5)}$ は, (a)多角形領 域に一様分布する点と $(\mathrm{b})$ 多角形領域に一様分布する点の間の $\underline{(\mathrm{c}) \text { 距 }}$ 離の赛乗の平均の近似值を求める手法を開発している。これは一般 性の高い方法で，近似式も簡易で扱いやすい。本論ではこれを，(a) 点に限定し, かつ(b)長方形に限定する代わりに，(c)距離だけでなく 角度を考慮したうえで, 厳密解を求めたものだと位置づけられる。

\section{3. 立論のための単純化}

我々が暮らすのは 3 次元空間であるが, 本論では以下 2 つの前提 に立ち, 議論を「平面上の点」のビジビリティに落とし込む。

\section{1. 視点集合の平面近似}

「視対象を見るすべての視点は, 近似的に同一の水平面上にある」 ことを前提とし，その水平面を「視点集合平面」と呼ぶ（Fig.1 の

「Plane of viewpoints」)。たとえば展示室の展示物に対する視点集 合平面は, 立位の鑑賞者における眼の高さの水平面であり, 教室の 黒板については座位の生徒のそれである。視点集合平面は壁やパネ ルなどの障害物によって境界づけられる（Fig.1の「Projected wall」）。

\section{2. 視対象の点近似}

視対象は面状もしくは 3 次元的オブジェクトであるので, 網膜に 映るその像は拡がりをもつ。しかしその拡がり方を示寸「立体角」 は, 「視点」と「視点集合平面上にある視対象の代表点」の位置関係 から精度よく換算できる（5.4.で述べる）。そこで視対象をその代表 点で近似する。ここでいう代表点とは「視対象の中心から視点集合 平面一下ろした垂線の足」のことである（Fig.1の「Representative point」)。この中心は, 通常は重心のことだが, 視対象内の情報度分 布に偏りがある場合は「情報度分布によって重みをつけた重心」の ことだとする。また視点集合平面のうち視対象の代表点を見ること のできる領域を「ビジブルエリア」と呼ぶことにする。

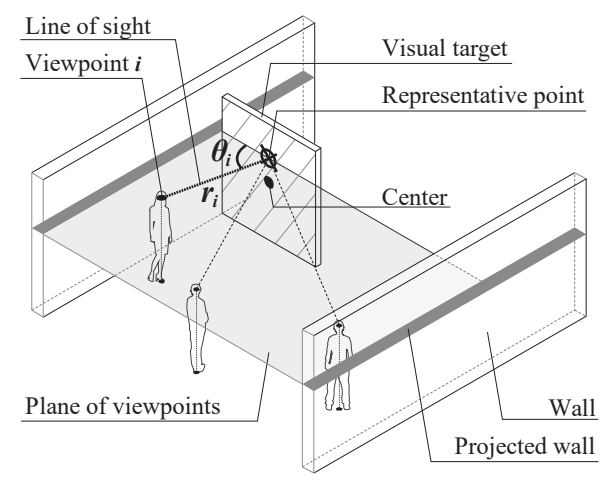

Fig.1 Visual target, viewpoint, and coordinate system setting

\section{4. ビジビリティ}

本論のゴールは, 部屋形状の評価および最適化である。評価対象 の部屋空間は 3 次元であり, 前章で述べたように視点集合を「平面」
で近似してもそれは 2 次元に過ぎない。しかし見やすさは, 固定さ れた「視点」—つまり空間内の 0 次元の「点」一一から評価され るべきと考えるのが自然である。そのため段階を踏んで演繹的に論 を展開する。本章ではまず「視点からの見やすさ」を議論し，6 章 において「部屋全体からの見やすさ」を議論する。

\section{1. 座標}

「視対象の代表点」を原点としたときの視点 $i$ の位置を極座標 $\left(r_{i}, \theta_{i}\right)$ で表す（Fig.1 に重补て描く）。ここで $r_{i}(>0)$ は視距離であ る。また $\theta_{i}\left(0 \leq \theta_{i} \leq \pi\right)$ は, 視対象が絵画やスクリーンなどの面状才 ブジェクトのときの，オブジェクト面と視線が成す角を表す。視線 がオブジェクト面と直交していれば $\theta_{i}=\pi / 2$, 一致していれば $\theta_{i}=$ 0 ないし $\theta_{i}=\pi$ である。ただし, 視対象が人物やある種の彫刻など の無方向性オブジェクトのときには, $r_{i}$ のみが視点位置の有意味な 変数になる。しかしその場合も, 便宜的に $\theta_{i}$ も導入したうえで一般 化して論を進めたうえで, 後述するパラメータ $\alpha$ (視対象を斜めに 見ることの負の影響度) をゼロにすることで $\theta_{i}$ の影響をキャンセル する。

\section{2. ビジビリティ関数}

ビジビリティとは「視点 $i$ から視対象を見たときの見やすさの度 合い」であり， $v_{i}(\geq 0)$ と表す。 $v_{i}$ は大きい方が望ましい。なお添字 の $i$ を省略することがある。ビジビリティ $v$ は, ビジビリティ関数 $f$ で記述されるとする。本節では妥当な $f$ を求める。

ビジビリティすなわち見やすさを規定する変数は, 視対象の種類 や色, 視対象内部のパターン, 周辺の光環境, 観測者の個人属性な ど, さまざまなものが考えられる。しかし主要な変数は，(i)視対象 の大きさ, (ii)視対象と視点の位置関係, の 2 ついってよいだろう。 ここで(i)を, 視対象の「代表的な面積」A(>0)で表す。そして(ii) を，4.1.で述べたとおり，(ii-1)視対象と視点の距離 $\boldsymbol{r}$, (ii-2)視対象 面と視線の成寸角度 $\theta$, の 2 值で表す。このときビジビリティ関数 $f$ は以下の 3 条件を満たすべきであろう。なお視対象に極端に近い 視点位置においてはこの 3 条件の成立は自明ではないが，これは問 題にならないことを補遺 1 で述べる。

条件(i) : 視対象が大きいほど網膜に映る像は大きくなるから， $f$ は 視対象の「代表的な面積」Aの増加関数である。

条件(ii-1) : 視点が視対象から遠ざかるほど網膜に映る像は小さくな るのでビジビリティは下がるべきだから,$f$ は視距離 $r$ の減少関数 である。

条件(ii-2) : 視対象を斜めに見るほど像が歪むのでビジビリティは下 がるべきだから, $f$ は偏角 $\theta$ の単峰関数で, 最大值をとるのは $\theta=$ $\pi / 2$ のときである。

条件(i)における視対象の「代表的な面積」 $A$ として, たとえば視 対象が黒板の場合にはその面積, 視対象が人間の場合にはその平行 投影面積を想定している。ただし実はこれをどのように設定しても 支障はない。なぜなら本研究の操作対象は視対象ではなく空間形態 だからである。言いかえると, 複数の部屋形状の案を比較するにあ たり, $A$ の值を変更しても, エリアビジビリティの值は全案に共通 して増減するので, その優劣順序に影響を与えないからである。し たがって条件(i)を満たす関数として, 最も単純な $A$ を採用しておく。 条件(ii-1)を満たす最も単純な関数は $\frac{1}{r}$ であろう。また「受けるエ ネルギーはその発生源からの距離の 2 乗に反比例する」という「逆 
2 乗則」から類推すると, $\frac{1}{r^{2}}$ が妥当な関数の候補となる。本研究で はこれを一般化して幕乗関数 $\frac{1}{r^{\beta}}$ を提案する。パラメータ $\beta(\geq 0)$ は視 点が視対象から遠ざかることの負の影響度を表す。 $\frac{1}{r^{\beta}}$ は, 視距離 $r$ がゼロのときに無限大に発散するという直感に反する性質をもつが, 補遺 1 で示したように, $r$ が小さな值のときのビジビリティを議論 する意味はないので, これは問題ない。

条件(ii-2)を満たす関数も候補は無数にあるが,「均等拡散面から 出る光度はその面の法線方向と成寸角の余弦に比例する」という「ラ ンベルトの余弦則」から類推すると, $\sin \theta$ が考えられる。なお余弦 でなく正弦になっているのは $\theta$ のり方が異なることによる見か けの違いにすぎない。本研究ではこれを一般化して $\sin ^{\alpha} \theta$ を提案す る。パラメータ $\alpha(\geq 0)$ は視対象を斜めに見ることの負の影響度を表 す。とくに $\alpha=0$ であることは, 視対象を斜めに見てもビジビリテ イへ影響が無いこと, つまり視対象が面状オブジェクトでなく無方

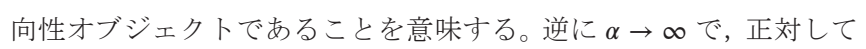
見ることに価值があり斜めに見ても意味がない視対象であることを 意味する。

「条件(i)から誘導される関数 $A 」$ と条件(ii-1)から誘導される関 数 $\frac{1}{r^{\beta}} 」$ と条件(ii-2)から誘導される関数 $\sin ^{\alpha} \theta 」$ を合体してビジビ リティ関数 $f$ にする際に, その妥当な合体演算は乗算であろう。な ぜならいずれかの関数值がたとえば半減したらビジビリティも半減 寸ると考えるのが自然だからである。以上をもって, ビジビリティ 関数として下式を提案する：

$$
v=f(r, \theta)=A \frac{1}{r^{\beta}} \sin ^{\alpha} \theta .
$$

式(1)のパラメータを, 上述の逆 2 乗則およびランベルトの余弦則 に基づき $\beta=2, \alpha=1$ と特定した下式も理論上重要である。なお視対 象が面状でなく無方向性のケース $(\alpha=0)$ も改めて示している。

$$
v=f(r, \theta)=\left\{\begin{array}{l}
A \frac{1}{r^{2}} \sin \theta \quad \text { (planar target) } \\
A \frac{1}{r^{2}} \text { (nondirectional target) }
\end{array}\right.
$$

式(2)の $f$ を「狭義ビジビリティ関数」ということにする。また一 般性を強調するときに, 式(1)の $f$ を「広義ビジビリティ関数」とい うこともある。

ところで, 例えば教室において黒板と教師が存在するように, 面 状の視対象と無方向性の視対象が 2 つ同時にあるときに, それらの ビジビリティをどのように合算するべきかを知りたい場合がある。 これについて補遺 2 で議論する。結論として, 面状視対象の狭義ビ ジビリティ $\frac{1}{r^{2}} \sin \theta$ と, 無方向性視対象の狭義ビジビリティ $\frac{1}{r^{2}}$ の妥当 な合成は, $\frac{1}{r^{2}} \sin ^{\alpha} \theta(0<\alpha<1)$ であると示される。

\section{5. 立体角の一般化としてのビジビリティ関数}

本章では, 狭義ビジビリティ関数式(2)が, 立体角の近似計算によ っても導出されることを示す。これにより, 広義ビジビリティ関数 式(1)は立体角を広く一般化した式だと理解できるようになる。

一旦, 4.2.で行ったビジビリティの定式化を考慮の外に置く。それ とは別の定式化として, 本章では,「ビジビリティは立体角と等しい」 と仮定する注1)。網膜に映る視対象の大きさは立体角で表せることか ら，この仮定はそれなりに正当化されよう。
本章では上記の仮定に基づいたうえで, 視対象の例として単純形 状のオブジェクトを 2 種とりあげ，その立体角を計算する。とりあ げる視対象は，人の頭やある種の彫刻などを想定した，方向性のな いオブジェクト「球」(5.1.) と, 黒板や絵画を想定した，方向性のあ るオブジェクト「長方形」(5.2.)である。

\section{1. 球を見込む立体角}

Fig. 2 に示寸ように, 半径 $c$ の球状の視対象が, その中心が視点集 合平面から $h$ 離れた位置にあり, 視対象の代表点（視対象の中心か ら視点集合平面一下ろした垂線の足）から $r$ 離れた場所に視点があ るとする。このとき視対象を見込む立体角 $\Omega_{\text {sphere }}$ を求めたい。なお これ以降, 立体角の単位はステラジアン $(\mathrm{sr})$ とする。

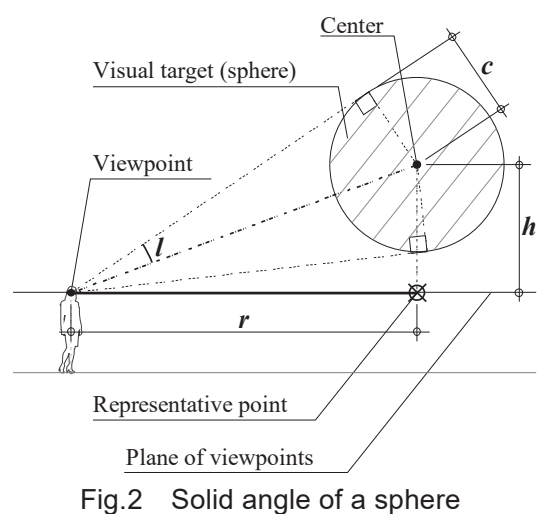

一般に, 半頂角 $l$ の錐をその頂点から見込んだ立体角は $2 \pi(1-$ $\cos l)$ であると知られている。この式の $l$ を $r, c, h$ で表して整理する ことで下式を得る：

$$
\Omega_{\text {sphere }}=2 \pi\left(1-\sqrt{1-\frac{c^{2}}{r^{2}+h^{2}}}\right) .
$$

\section{2. 長方形を見込む立体角}

Fig.3 に示すように, 視点集合平面と直交した縦 $a$ 横 $b$ の長方形 の視対象が，その中心が視点集合平面から $h$ 離れた位置にあり，視 対象の代表点から $r$ 離れた場所に視点があり, 代表点と視点を結ぶ 線分（視線）と長方形平面が成す角を $\theta$ とする。このとき視対象を 見込む立体角 $\Omega_{\text {rectangle }}$ を求めたい。

文献 ${ }^{6)}$ の結果を応用すると, Fig. 3 に示す 4 角 $m_{1}, m_{2}, n_{1}, n_{2}$ を用い て，長方形を見込む立体角は下式で表せる：

$$
\begin{aligned}
\Omega_{\text {rectangle }}= & \arcsin \left(\sin m_{1} \sin n_{1}\right)+\arcsin \left(\sin m_{2} \sin n_{2}\right) \\
& -\arcsin \left(\sin m_{1} \sin n_{2}\right)-\arcsin \left(\sin m_{2} \sin n_{1}\right) .
\end{aligned}
$$

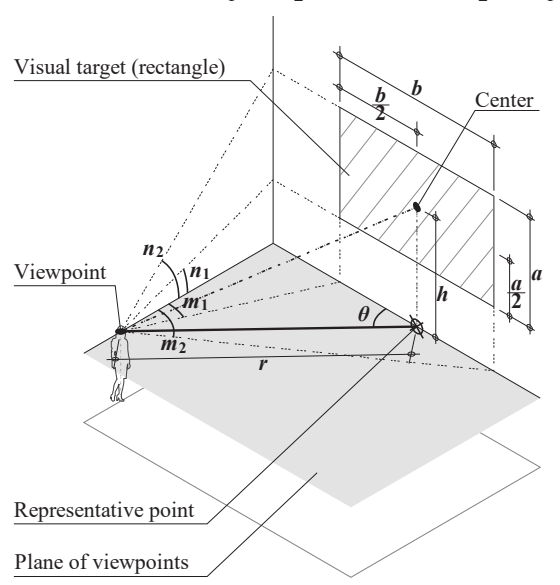

Fig.3 Solid angle of a rectangle 
式(4)の $m_{1}, m_{2}, n_{1}, n_{2} を r, \theta, a, b, h$ で表して整理し, 下式を得る：

$\Omega_{\text {rectangle }}=$

$$
\begin{aligned}
& \arcsin \frac{(a-2 h)(b-2 r \cos \theta)}{\sqrt{\left(b^{2}+4 r^{2}-4 b r \cos \theta\right)\left[(a-2 h)^{2}+4 r^{2} \sin ^{2} \theta\right]}} \\
& +\arcsin \frac{(a-2 h)(b+2 r \cos \theta)}{\sqrt{\left(b^{2}+4 r^{2}+4 b r \cos \theta\right)\left[(a-2 h)^{2}+4 r^{2} \sin ^{2} \theta\right]}} \\
& +\arcsin \frac{(a+2 h)(b-2 r \cos \theta)}{\sqrt{\left(b^{2}+4 r^{2}-4 b r \cos \theta\right)\left[(a-2 h)^{2}+4 r^{2} \sin ^{2} \theta\right]}} \\
& +\arcsin \frac{(a+2 h)(b+2 r \cos \theta)}{\sqrt{\left(b^{2}+4 r^{2}+4 b r \cos \theta\right)\left[(a-2 h)^{2}+4 r^{2} \sin ^{2} \theta\right]}}
\end{aligned}
$$

\section{3. 立体角の近似}

以上, 球の立体角 $\Omega_{\text {sphere }}$ および長方形の立体角 $\Omega_{\text {rectangle }}$ をそれぞ れ求めた（これらをまとめて立体角 $\Omega$ と書くことにする）。しかし この式のままでは, 変数が多く, かつ視対象の形状に固有の議論に なってしまうため，見通しが良くない。そのため立体角 $\Omega$ の近似表 現を得ることで，2式の統一化を目指す。

補遺 1 に示したように, 本論の趣旨に照らすと視対象至近のビジ ビリティを議論することに意味はない。したがって立体角 $\Omega$ の近似 をするにあたっても, 視距離 $r(>0)$ が長いところでの近似誤差は小 さい必要がある一方で， $r$ が短いところでの誤差は許容できる。そ の観点から, それぞれの $\Omega$ を $r=\infty$ のまわりで 2 次の項までテイラ 一展開することで，下式を得る。具体的な計算法は注注2)に示す。

$$
\begin{array}{ll}
\Omega_{\text {sphere }} \approx \pi c^{2} r^{-2} & \text { as } r \rightarrow \infty \\
\Omega_{\text {rectangle }} \approx a b \sin \theta r^{-2} & \text { as } r \rightarrow \infty
\end{array}
$$

上式それぞれの右辺は，狭義ビジビリティ関数式(2)の右辺と本質 的には同じ式である。なぜなら，式(2)右辺の「視対象の代表面積」 $A$ を, 視対象が球 $\left(\Omega_{\text {sphere }}\right)$ の場合は「円の面積」 $\pi c^{2}$ とみなし, 視 対象が長方形 $\left(\Omega_{\text {rectangle }}\right)$ の場合は「長方形の面積」 $a b$ とみなすのが 自然だからである。なお，たとえ $A$ を $\pi c^{2} や ~ a b$ とみなすことを認め なくとも支障はない。というのも, 前述のとおり $A$ は, 視点位置に よらない正定数のため, 部屋形状の最適化の結果に影響を与えない からである。

このように, 狭義ビジビリティ関数式(2)は, 立体角の近似式(6)(7) と本質的に一致する。ところで, 広義ビジビリティ関数式(1)のパラ メータを $\beta=2, \alpha=1$ と特定すると式(2)になるのであった。したが って式(1)は，立体角を広く一般化した式だと理解できる。

\section{4. 近似の精度評価}

本節では，前節で行ったテイラー近似の精度評価を行う。具体的 には, 球型の視対象として人間の頭部を, 長方形の視対象として絵 画および黒板を想定し, 計 3 パターンの視対象について大きさと中 心高さを設定した。それらに対し，厳密な立体角を表す式(3)と(5)お よび，その近似としての狭義ビジビリティ関数式(2)（すなわち式(6) と（7）をそれぞれ計算した。またその相対誤差として，「(近似值一 峳密值）／厳密值」も算出した。それぞれの值についての空間分布 を Fig.4 にまとめる。

Fig.4 をみると, 立体角 (左列) と, その近似としての狭義ビジビ リティ関数（中列）の分布形状は，極めてよく似ている。じっさい 視対象から $5 \mathrm{~m}$ ほど離れたところでの相対誤差は，人間の頭部は 1 万分の 1 のオーダー, 小さめの絵画 (「モナ・リザ」サイズ) は千分 の 1 のオーダーであり, 近似の精度はとても高い。つまり小さめの 視対象に対しては, 立体角と狭義ビジビリティ関数はほぼ等しい。
また，大きさを持った視対象をその代表点で近似することの妥当性 が傍証されたといえる。

これに対し，視対象が黒板（縦 $1.2 \times$ 幅 $3.6 \mathrm{~m}$ ）の場合はそうとも いえない。Fig.4の右下に重ねて描いたように, 平均的な形状の小学 校教室において, 座席が配置されて生徒の視点が存在する領域を考 える。教室の形状を微小変更するときにエリアビジビリティ(後述) に影響をあたえるのは，当該領域のコの字型の境界部分（図のグレ 一部分）なので，そこでの相対誤差に興味がある。そこにおいて最 も近似精度の悪い場所は手前の角であり，その相対誤差は-0.2 程 度であった。上記以外にも視対象の大きさを変えて実験したところ， 共通した性質として，視対象の大きさに比べて視対象に近い場所に おいては，近似精度がそれほど高くないことが分かった。ただしい ずれの場合も，立体角と狭義ビジビリティ関数の分布形状はよく似 ている。部屋形状最適化を行ううえで，ビジビリティ分布の系統的 な誤差（たとえば定数倍されたり定数和されたりする誤差）は結果 に影響を与えないので，立体角と狭義ビジビリティ関数は等しいと 考えておおむね問題にならないと考えている。
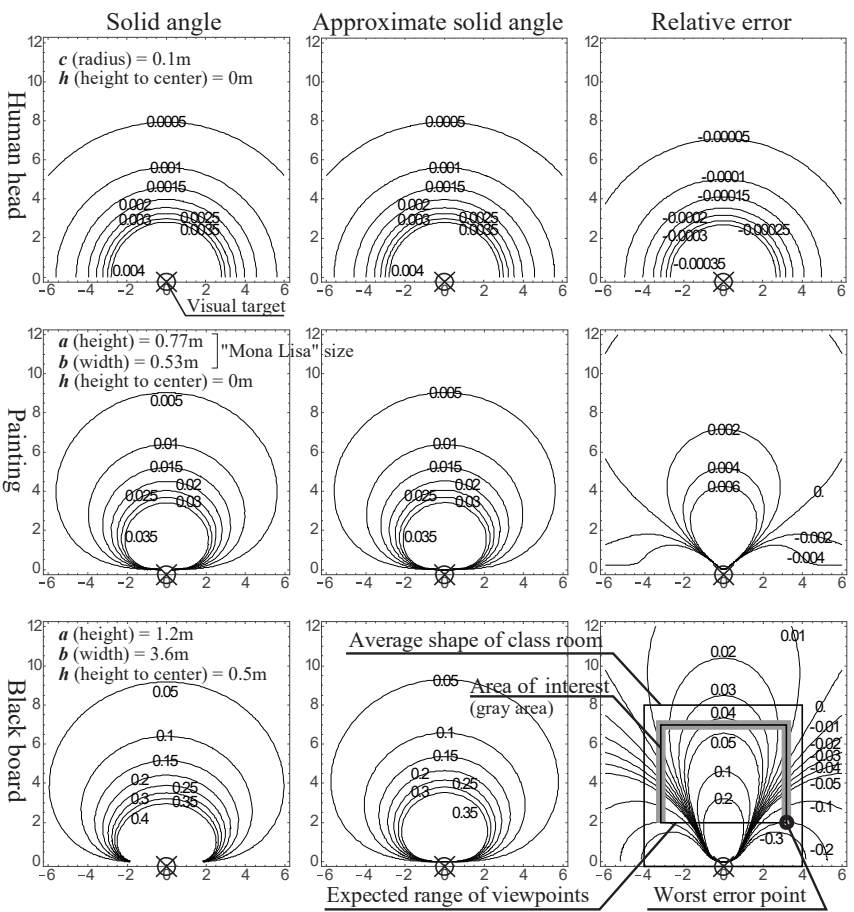

Fig.4 Evaluation of approximate solid angle for 3 examples

\section{6. エリアビジビリティ}

4 章と 5 章では「視点からの見やすさ」を定式化した。本章では, これをもとに「部屋全体からの見やすさ」を議論する。

エリアビジビリティを「ビジブルエリア全域から視対象を見たと きの見やすさの度合いによって規定される, 部屋形状の評価值」と 定義し, $g(\geq 0)$ と表す。ビジビリティ $v_{i}$ はある視点 $i$ からの視対象 の見や寸さを表していた。これに対しエリアビジビリティ $g$ は， $v_{i}$ の集計值であり,ビジブルエリア全体からの見やすさを表している。 $g$ は大きい方が望ましい。部屋形状がパラメータベクトル $\boldsymbol{a}$ で表さ れるとすると, エリアビジビリティは $g(\boldsymbol{a})$ と表現可能であり, 「 $g(\boldsymbol{a})$ を最大化する $\boldsymbol{a}$ を探る問題」が建築計画学的に重要な問題になる。 そのときに本論では「部屋の面積は $\boldsymbol{a}$ によらず一定」という制約条 
件をつける。そうする理由は, 床面積は建設費や維持費と比例関係 にあると考えるのが自然であり, コスト一定の条件下でのエリアビ ジビリティが計画上重要な指標になるからである。

エリアビジビリティを数式で表すにあたり，単純な想定に基づく と,「ビジブルエリアに均質かつ稠密な視点 $i=1, \ldots, n$ を設定し, ビ ジビリティ $v_{i}$ を全視点にわたって足し合わせると, エリアビジビリ ティ $g=\sum_{i=1}^{n} v_{i}$ になる」と定義するのが自然であろう。このときビ ジブルエリアの面積が一定ならば, 「ビジビリティ $v_{i}$ の相加平均が エリアビジビリティ $g=\frac{1}{n} \sum_{i=1}^{n} v_{i}$ である」と定義しても同じことで ある。

しかしこの定式化には $2 つ の$ 前提が必要である。(i)ひとつは視点 の分布が均斉であること。たとえば教室・劇場において座席が均一 に分布していて, 面積あたりの学生・観客の視点数が一定という前 提である。(ii)もうひとつは, 部屋形状の評価值（エリアビジビリテ イ）は，視点からの評価值（ビジビリティ）の単純和であること。 そのときには, ある場所のビジビリティを減らし, 同じ量だけ別の 場所のビジビリティを増やしても, エリアビジビリティは変わらな いことになる。

しかし上記の前提が成り立たない場合は多い。たとえば空いてい る展示室においては, 鑑賞者は鑑賞位置を自由に決められる（(i)に 反するケース)。そのときには, 見づらい場所はある種切り捨て, 見 やすい場所をより重視することが必要になる。一方で小学校の教室 においては, 公平なビジビリティ分布が望まれる（(ii)に反するケー ス)。そのときには, 見やすい場所を多少減らしてでも, 見づらい場
所を底上げすることが必要になる。

以上の考察から，「見やすい場所（あるいは見づらい場所）を重視 する度合い」を操作できればよいことが分かる。そこで，その度合 いをパラメータ $p(\neq 0)$ として組み込み, エリアビジビリティはビ ジビリティの一般化平均（Generalized mean）であると提案する：

$$
g=\left(\frac{1}{n} \sum_{i=1}^{n} v_{i}^{p}\right)^{1 / p} .
$$

以下，この定式化におけるパラメータ $p$ とエリアビジビリティ $g$ の関係について述べる。まず指摘できることは, 特定の $p$ の值を選 ぶと, $g$ はビジビリティ $v_{1} \ldots v_{n}$ の, 最小值・調和平均・相乗平均・ 相加平均・最大值という様々な集計值になることである(Table 1 の, 見出し列を除いた 1 列目)。よってこの $\mathrm{g}$ は, 「ビジビリティの相加 平均」を一般化した指標だといえる。また厚生経済学の知見から, $p$ は「非公平性」すなわち「ビジビリティ分布がどのくらい偏るの を是とするか」を表すパラメータだと解釈できる（Table 1 の 2,3 列目)。具体的には, $p$ が小さな值のときは, 場所によらず公平な見 やすさを志向する状況を表す［例えば教室における黒板の見やすさ を評価するケース］。 $p=1$ のときは, ビジビリティの総和を問題に する状況を表す［例えば入場料とビジビリティが比例関係にあると きのホールにおけるステージ]。 $p$ が大きな值のときは, ベストポジ ションからの見やすさを偏重する状況を表す［例えば展示室におけ る展示物] (Table 1 の，6 列目)。このように $p$ を適切な值に設定 することで，多様な部屋用途や社会通念を評価できるのである。

Table1 Examples of applications corresponding to various exponents $p$

\begin{tabular}{|c|c|c|c|c|c|c|c|}
\hline & \multirow{2}{*}{$\begin{array}{l}\text { Value of area } \\
\text { visibility } g \\
\text { エリアビジビリ } \\
\text { ティ } g \text { の值 } \\
g=\left(\frac{1}{n} \sum_{i=1}^{n} v_{i}^{p}\right)^{1 / p}\end{array}$} & \multirow{2}{*}{$\begin{array}{l}g \text { as social } \\
\text { welfare } \\
\text { function } \\
g \text { を社会的 } \\
\text { 厚生関数だ } \\
\text { とみなすと }\end{array}$} & \multirow{2}{*}{$\begin{array}{l}\text { What kind of } \\
\text { visibility } \\
\text { distribution is } \\
\text { good? } \\
\text { どのようなビジ } \\
\text { ビリティ分布を } \\
\text { 是とするか? }\end{array}$} & \multirow{2}{*}{$\begin{array}{l}\text { Planning } \\
\text { principle to } \\
\text { maximize } g \\
g \text { を最大化 } \\
\text { するための } \\
\text { プランニン } \\
\text { グ方針 }\end{array}$} & \multicolumn{2}{|c|}{$\begin{array}{c}\text { Examples of applications } \\
\text { 適用例 }\end{array}$} \\
\hline & & & & & & $\begin{array}{c}\alpha=1 \quad \text { (planar target) } \\
\text { (面状の視対象) }\end{array}$ & $\begin{array}{c}\alpha=0 \quad \text { (nondirectional } \\
\text { target) } \\
\text { (無方向性の視対象) }\end{array}$ \\
\hline \multirow{5}{*}{$\begin{array}{l}4 \\
2 \\
2 \\
0 \\
0 \\
0 \\
0 \\
0 \\
0 \\
0 \\
0 \\
0 \\
2 \\
0 \\
0\end{array}$} & $p \rightarrow-\infty$ & 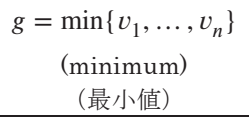 & $\begin{array}{l}\text { Rawls-type } \\
\text { ロールズ型 } \\
\text { (max-min) } \\
\end{array}$ & \multirow{3}{*}{$\begin{array}{l}\uparrow \\
\text { Equal } \\
\text { distribution is } \\
\text { good } \\
\text { 公平な分布が良 } \\
\text { い }\end{array}$} & \multirow{4}{*}{$\begin{array}{l}\uparrow \\
\text { Reduce bad } \\
\text { place } \\
\text { 見づらい場 } \\
\text { 所を減らす }\end{array}$} & \multirow{3}{*}{$\begin{array}{l}\text {-Black board in } \\
\text { classroom } \\
\text {-Screen in theater } \\
\text {-教室における黒板 } \\
\text {-映画館におけるスク } \\
\text { リーン }\end{array}$} & \multirow{3}{*}{$\begin{array}{l}\text {-Teacher in classroom } \\
\text {-教室における講師 }\end{array}$} \\
\hline & $p=-1$ & $\begin{array}{l}g=\frac{n}{\frac{1}{v_{1}}+\cdots+\frac{1}{v_{n}}} \\
\begin{array}{c}\text { (harmonic mean) } \\
\text { (調和平均) }\end{array}\end{array}$ & - & & & & \\
\hline & $p \rightarrow 0$ & $\begin{array}{c}g=\left(v_{1} v_{2} \ldots v_{n}\right)^{\frac{1}{n}} \\
\text { (geometric mean) } \\
\quad \text { 相乗平均 })\end{array}$ & $\begin{array}{l}\text { Nash-type } \\
\text { ナッシュ型 }\end{array}$ & & & & \\
\hline & $p=1$ & $\begin{array}{c}g=\frac{v_{1}+\cdots+v_{n}}{n} \\
\text { (arithmetic mean) } \\
\quad(\text { 相加平均) }\end{array}$ & $\begin{array}{l}\text { Bentham- } \\
\quad \text { type } \\
\text { ベンサム型 } \\
\text { (max-sum) }\end{array}$ & $\begin{array}{l}\text { Total amount of } \\
\text { visibility is } \\
\text { important ※ } \\
\text { ビジビリティの } \\
\text { 総和が重要 ※ }\end{array}$ & & $\begin{array}{l}\text {-Stage in box-type } \\
\text { theater } \\
\text {-シューボックス型劇 } \\
\text { 場におけるステージ }\end{array}$ & $\begin{array}{l}\text {-Stage in arena-type } \\
\text { theater } \\
\text {-アリーナ型劇場における } \\
\text { ステージ }\end{array}$ \\
\hline & $p \rightarrow \infty$ & $\begin{array}{c}g=\max _{(\operatorname{maximum})}\left\{v_{1}, \ldots, v_{n}\right\} \\
(\text { 最大値 })\end{array}$ & $\begin{array}{l}\text { Nietzsche- } \\
\quad \text { type } \\
\text { ニーチェ型 } \\
(\max -\max )\end{array}$ & $\begin{array}{l}\text { The most } \\
\text { visible place is } \\
\text { important } \\
\text { ベストポジショ } \\
\text { ンからの見やす } \\
\text { さを偏重 } \\
\downarrow\end{array}$ & $\begin{array}{l}\text { Expand } \\
\text { good place } \\
\text { 見やすい場 } \\
\text { 所を増やす } \\
\downarrow\end{array}$ & $\begin{array}{l}\text {-Painting in } \\
\text { exhibition room } \\
\text {-TV in living room } \\
\text {-展示室における絵画 } \\
\text {-リビングにおけるテ } \\
\text { レビ }\end{array}$ & $\begin{array}{l}\text {-Sculpture in exhibition } \\
\text { room } \\
\text {-展示室における彫刻 }\end{array}$ \\
\hline
\end{tabular}

※ Total tickets' sales is important when tickets' fee is proportional to the visibility of the seat at a concert. ※ 例えばコンサートのようにチケット代がその席のビジビリティと比例するときの，総チケット売上を重視する状況。 
また計算上は，式(8)を空間的に連続化して，

$$
g=\left(\frac{1}{S} \int_{B} v^{p} d u\right)^{1 / p}
$$

とする。ここで積分範囲である領域 $B$ はビジブルエリアを表し,$d u$ はその微小面積を表す。 $S$ はビジブルエリアの面積 $\int_{B} d u$ である。

\section{7. 長方形領域のエリアビジビリティ}

本章では，4章で定式化したビジビリティを用いて，6 章で定式 化したエリアビジビリティを実際に計算する。

本章で扱うのは, 幅 $w$ 奥行 $d$ の長方形プランの部屋において, 正 面中央に視対象が設置されている状況である。この視対象は, 学校 教室における黒板, 映画館におけるスクリーン, 展示室における絵 画などを想定している。このとき視対象を原点とする直交座標を Fig. 5 のように張る。視対象に近い「y が 0 から $\epsilon d$ の範囲」 $(0 \leq \epsilon<$ 1) はビジブルエリアではない,つまり視点が存在しないゾーンとし て扱う。このゾーンは，教室であれば教壇，映画館であればスクリ ーン前の座席のないスペース, 展示室であれば絵画近くの立ち入り 禁止エリアを意味する。

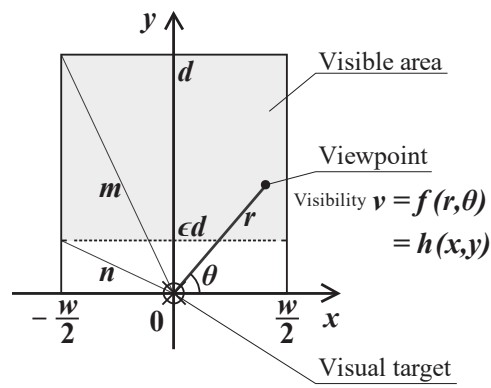

Fig.5 Shape of visible area and coordinate system

まずビジビリティ関数を表す式(1)に対して, 極座標系 $(r, \theta)$ を直 交座標系 $(x, y)$ に変換し, 下式を得る。ただしここでは, 部屋形状の 評価に無関係である「視対象の代表的な面積 $A$ 」を無視している。

$$
v=\frac{y^{\alpha}}{\left(x^{2}+y^{2}\right)^{\frac{\alpha+\beta}{2}}} .
$$

次にエリアビジビリティは, 定義式(9)から，下式で表現できる

$$
g=\left(\frac{2}{w d(1-\epsilon)} \int_{\epsilon d}^{d} \int_{0}^{\frac{w}{2}} v^{p} d x d y\right)^{\frac{1}{p}} .
$$

この準備を経て，式(11)に式(10)を代入して 2 重積分を解きたい。 すなわちエリアビジビリティ $\mathrm{g}$ を初等関数のみで陽に表したい。も しこれができれば，各種パラメータとエリアビジビリティを直結し て理解できるので, 非常に有用である。そのため数多の試行錯誤を 重袢たが，一般の $\alpha, \beta, p$ についてエリアビジビリティ $g$ を陽に表す

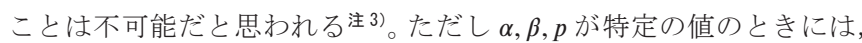
それができるケースがあることを発見した。その中で解釈上重要な ものを次ページの Table 2 にまとめる。それぞれの導出過程は非常 に煩雑である注4)。よって結果のみを示している。

Table 2 により,「 $\alpha$ と $\beta$ で表される視認感覚や視対象特性」と「 $p$ で表される部屋用途や社会通念」を,「エリアビジビリティ $g$ という 部屋形状の評価值」に直結できたといえる。これにより第一に, $\alpha, \beta, p$ という 3 つのパラメータ（実質的には 2 つに退化）を設定し，
かつ部屋の幅 $w$, 奥行 $d$, 視点が存在しないゾーンの奥行 $\epsilon d$ を入力 することで，エリアビジビリティを直ちに求められる。すると複数 の部屋形状を客観的に比較できる。第二に，パラメータの変化に対 するエリアビジビリティの感度分析を行うことができる。すなわち, 視認感覚・視対象特性・部屋用途・社会通念・部屋形状を変化させ たときに，部屋の評価值がどう変動するかが分かるのである。

\section{8. 長方形プランの部屋の形状最適化}

前章で, 長方形領域のエリアビジビリティを求めた。本章ではこ れをもとに, 最適な部屋形状を導出する。すなわち, 面積を所与と する長方形プランの部屋において，ひとつの壁の中央に視対象を設 置したときの，部屋のエリアビジビリティを最大化するような，最 適な部屋の幅と奥行を導出する。想定している適用先は，黒板ある いは教師を見やすい教室の形状 ( $p$ が小さな值のとき), スクリーン を見やすい映画館の形状（ $p$ が小さな值のとき），ステージを見やす い劇場の形状（ $p=1$ のとき）, 絵画を見やすい展示室の形状（ $p$ が 大きな值のとき）などである。

様々なパラメータの組について求めた最適形状を次ページの Table 3 にまとめる。なお所与の面積が例えば 2 倍になっても，ビ ジビリティの定義式上，最適な部屋の奥行と幅がそれぞれ $\sqrt{2}$ 倍に なるだけで，プロポーションには影響を与えない。そこで重要な指 標として最適な「奥行-幅」比を表に記し，その形の模式図も同時に 描いている。

Table 3 および感度分析から得られた定性的な知見を以下にまと める。

（1）視対象が面的になるほど（ $\alpha$ が 1 に近づくほど）, 最適部屋形状 は奥行が深くなる。逆に無方向的になるほど（ $\alpha$ が 0 に近づく ほど), 幅が広くなる。たとえば学校において, 黒板のビジビリ ティが重要な講義型の教室は奥行が深くあるべきで, 講師のビ ジビリティが重要な参加型の教室は幅広くあるべき, という通 念と整合している。

（2）視距離について，ビジビリティが立体角に等しいとき（ $\beta=2$ の とき), 最適部屋形状は幅が広い。これに比べて, 離れることの 負の影響度が低くなると ( $\beta$ が 0 に近づくと), 奥行が深くなる。

（3）公平性が高い用途のとき（ $p$ が小さな值のとき：教室など $)$, 最 適形状は奥行が深くなる。これは, 幅が広いときには視対象側 手前の角部が際立ってビジビリティが低くなってしまうので, そのエリアを無くしたいからである。一方べストポジションか らの見やすさを重視する用途のとき（ $p$ が大きな值のとき：展 示室など)，幅が広くなる。

（4）立入禁止エリアが広いほど（ $\epsilon$ が 1 に近づくほど $)$, 最適形状は 幅が広くなる。逆に狭いほど（ $\epsilon$ が 0 に近づくほど $),$ 奥行が深 くなる。これは, ビジビリティの高い場所を立入禁止エリアに 充てたくないからである。

これらはいずれも直感的に納得できる性質であり，ある種当たり 前でもある。しかしこれらの定性的な性質を数值的に評価でき，感 度分析も可能で，しかも相反する各パラメータをどのような值に設 定しても最適形状を求められるところに, 本論の有用性と独自性が ある。

計画時に考慮すべき事項は，もちろんビジビリティ以外にも存在 
する。たとえば教室では座席配置のしやすさ, 劇場では音響の良さ, 展示室では動線のスムースさも, 重要なプランニング要件である。 しかし本手法によって, エリアビジビリティを独立して数值的に評 価できる。他の要件と併せて多目的な最適化を行う前段の基礎的な 知見として有用であろう。

\section{9. まとめ}

本稿では, 教室における黒板, 劇場におけるステージ, 展示室に おける絵画などを見やすくさせる部屋の形状を理論的に導出した。 (i)まず任意の視点からの「ビジビリティ」を表す妥当な関数を提案
した。ここで視対象を斜めに見ることの負の影響度 $\alpha$ と，視対象か ら遠ざかることの負の影響度 $\beta$ を導入した。(ii)次にビジビリティの 妥当な集計方法を提案し, 部屋全体の評価值「エリアビジビリティ」 を求めた。ここでビジビリティ分布の不公平度 $p$ を導入した。(iii)最 後にエリアビジビリティを最大化する, 最適な部屋の形状を導出し た。結論として,「 $\alpha$ と $\beta$ で表される視認感覚や視対象特性」と「 $p$ で表される部屋用途や社会通念」を決めると, 部屋の最適形状が直 ちに求まるようになった。これは, 従来経験的に行われてきたビジ ビリティ評価を客観的に行うための補助線として, 有用な知見だと 考えている。

Table2 Area visibility $g$ corresponding to various parameter sets

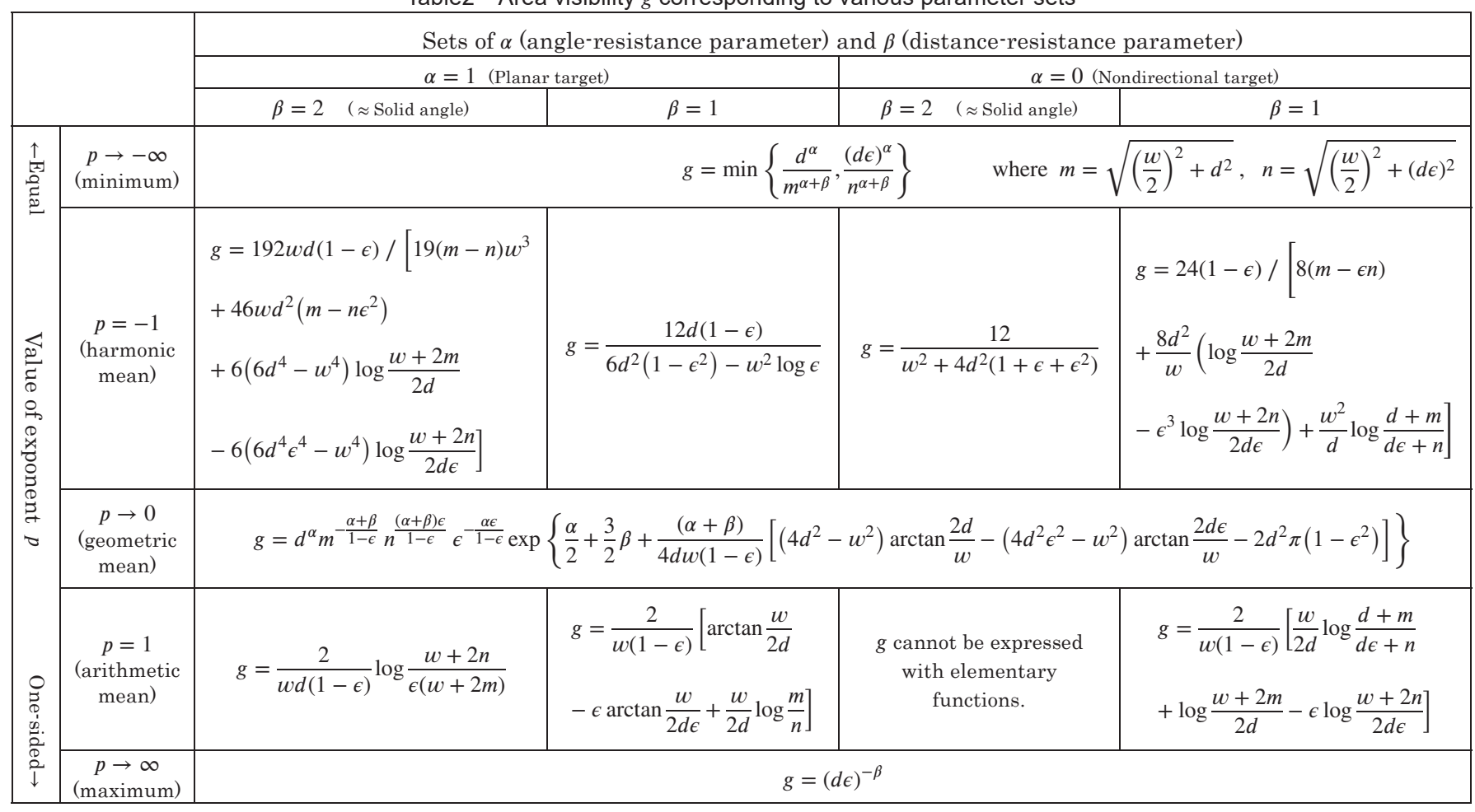

Table3 Optimal plan to maximize area visibility corresponding to various parameter sets

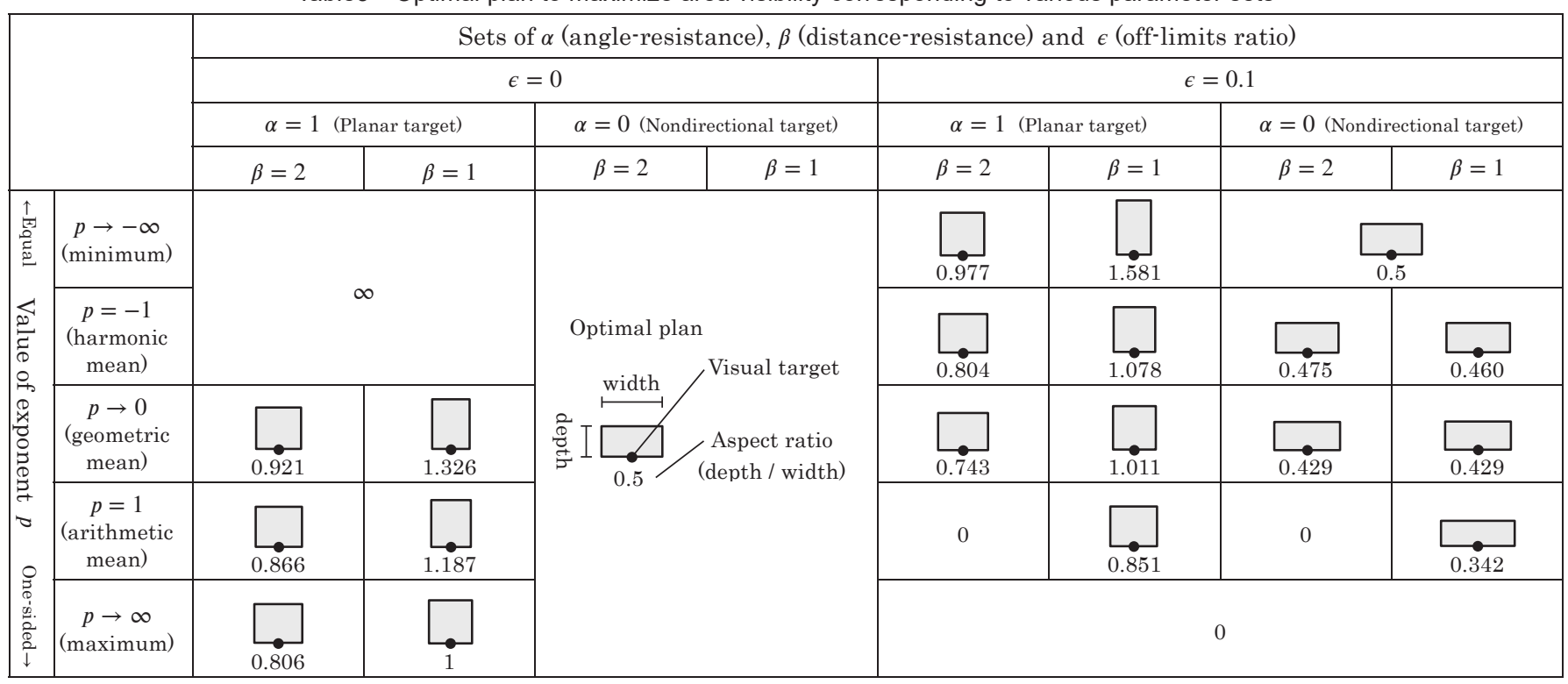




\section{謝辞}

本研究は JSPS 科研費 JP15H02974, JP16K20971 の助成を受 けたものです。またエリアビジビリティの導出にあたり栗田治先生 (慶應義塾大学) に重要な助言をいただきました。ここに謝意を表し ます。

\section{補遺 1 視対象至近のビジビリティ不定性とその無影響性}

本補遺では, 視対象の大きさに比べて視対象に極端に近い視点からのビジ ビリティについて議論する。そのような視点においては, 4.2.で述べた条件(i), (ii-1)，(ii-2)の成立は自明でないことを述べたうえで，しかしながらそれが問 題にならないことを示す。

たとえば視対象が映画スクリーンの場合，一般にスクリーンは大きくかつ 席は近い方が見やすい。しかし大きすぎるあるいは近すぎると，全体を一望 寸るのが難しくなるため, むしろ見やすさは下がるだろう (条件(i)あるいは 条件(ii-1)が不成立のケース)。一方で視対象が横に長い絵画の場合に, 絵画 の中心正面に立つ鑑賞者が，その中心つまり代表点からの距離を保ったまま サイドに回り込むと, 絵画の一部分に対しては視距離が近くなるので, むし ろ見やすさが上がることもあろう（条件(ii-2)が不成立のケース）。このよう に, 視対象至近でのビジビリティは, 視対象の種類や大きさあるいは見る人 の視認感覚によって異なり，一般化して定式化するのが難しい。

しかし上記の問題は, 本研究の最終目的である「部屋形状の評価」に向か って論展開していく際には, おおむ放支障にならない。なぜなら, 視対象至 近に壁などの障害物が配置されるとは考えづらく, またそのような部屋形状 が最適解になることもありえないからである。よって部屋形状の案を複数比 較するに際し, どの案も必ず視対象至近は全域がビジブルエリアになるため, 視対象至近のエリアビジビリティの值は案による差が無いと考えてよい。だ から視対象至近のビジビリティ関数を変えても, エリアビジビリティに対す るその変更の影響は全ての案に共通して加算減算されるだけなので, 案どう しのエリアビジビリティの差は変わらず，その優劣順序も変わらない。した がって視対象至近のビジビリティをどのような関数で表そうとも, 部屋形状 の優劣に影響を与えないのである。

\section{補遺 2 教室における黒板と教師の合成ビジビリティ}

本補遺では, 教室において黒板と教師という 2 種の視対象が存在するとき, それらの狭義ビジビリティを合成する方法について議論する。

式(2)から，面状オブジェクトである黒板の狭義ビジビリティ $v$ 黒板を， $A$ 黒板 $1 / r^{2} \sin \theta$ で表す。また無方向性オブジェクトである教師の狭義ビジビ リティ $v$ 教師を， $A$ 教師 $1 / r^{2}$ で表す。これは, 黒板は斜めから見ると見づらい のに対し, 教師は体の向きを変えるのでそうではないという前提に基づいて いる。また教師は黒板の中央に立ちがちと考え, 黒板と教師の代表点は一致 しているとする。教師によって黒板が隠れる影響は，場所によらず一定で， 部屋形状評価のうえでは無視できるとする。

そのとき黒板と教師を合わせた合成ビジビリティ $v$ 合成をどのように定式 化すべきだろうか。単純に考えると, $v$ 黒板と $v$ 教師を, それぞれの重要度 で重みをつけたうえで相加平均をとるといら定式化を思いつくが，これは不 適切といえる。なぜなら黒板と教師のどちらか片方がほとんど見えなければ, もう片方がよく見えたとしても, 視覚体験の満足度は著しく低いはずなので, 全体としてのビジビリティはゼロに近づくべきであるが，上記の定式化では それが達成できないからである。そこで, $v$ 合成を, $v$ 黒板と $v$ 教師の重み付 き相乗平均（weighted geometric mean）で表すことにする:

$$
v_{\text {合成 }}=\left(v_{\text {黑板 }}{ }^{\mu_{\text {黑板 }}} v_{\text {教師 }} \mu^{\mu_{2}} \text { 師 }^{\frac{1}{\mu^{\text {黑板 }}+\mu^{\mu_{2}}}}\right.
$$

ここで $\mu$ 黒板 と $\mu$ 教師は, それぞれ黒板と教師の相対的な視覚的重要性を表す 正の数である。この式に, 上述の $v$ 黒板 と $v$ 教師の定義式を代入して整理す ることで下式を得る：

$$
\begin{aligned}
& v_{\text {合成 }}=A_{\text {合成 }} \frac{1}{r^{2}} \sin ^{\alpha} \theta \\
& \text { ただし } A_{\text {合成 }}=\left(A_{\text {黒板 }}{ }^{\mu_{\text {黑板 }}} A_{\text {教師 }}{ }^{\mu_{\text {教師 }}}\right)^{\frac{1}{\mu^{\text {黑板 }}+\mu^{-u_{2}}}}, \quad \alpha=\frac{\mu_{\text {黑板 }}}{\mu_{\text {黑板 }}+\mu_{\text {教師 }}}
\end{aligned}
$$

上式から， $A$ 黒板 は部屋形状の評価順序に影響を与えない正定数であり， 合成ビジビリティ $v$ 合成の本質は $1 / r^{2} \sin ^{\alpha} \theta$ で表現できると分かる。すなわち $v$ 合成 は広義ビジビリティ関数式(1)の特殊ケースと理解できる。またパラメ 一タ $\alpha$ は， $0<\alpha<1$ をとり， $\mu$ 黒板 《 $\mu$ 教師 のとき 0 に近づき， $\mu$ 教師 $\mu$ 黒板のとき 1 に近づく。
1) Hirasawa Y., Ukai T, and Kurita O.: Ratio of visible green associated with pedestrian location and visual line - Solid angle calculation introducing sphere model, Journal of the City Planning Institute of Japan, Vol.52, No.3, pp.1276-1283, 2017.10. (in Japanese)

平澤雄基, 鵜飼孝盛, 栗田治: 歩行者の位置と視線を反映した並木の緑視 率一球体モデルに基づく立体角の計算方法，日本都市計画学会都市計画論 文集, Vol.52, No.3, pp.1276-1283, 2017.10.

2) Hirabayashi S., Kurita O., and Ukai T.: Distance- and distortion-based appreciation spot decision model, Abstracts. Spring National Conference of Operations Research Society of Japan, Vol.2017, pp.41-42, 2017.3. (in Japanese)

平林新, 栗田治, 鵜飼孝盛：対象までの距離と歪み指標に基づく絵画鑑賞 位置決定モデル, 日本オペレーションズ・リサーチ学会春季研究発表会ア ブストラクト集, Vol.2017, pp.41-42, 2017.3.

3) Sato T., Takatori A., Satoh Y.: Visibility evaluation method for auditorium design using visible area ratio, Journal of Architecture and Planning (Transactions of AIJ), Vol.82, No.737, pp.1695-1702, 2017.7. (in Japanese)

佐藤大樹, 高取昭浩, 佐藤康弘：可視率を用いた観客席設計のための舞台 一の見通し評価手法に関する研究，日本建築学会計画系論文集，Vol.82， No.737, pp.1695-1702, 2017.7.

4) Kurita, O.: The average and the second moment of Euclidean distance from points uniformly distributed in a polygon to fixed point - A way to draw the contours of the average Euclidean distance, Geographic Information Systems Association, Vol.9, No.1, pp.29-37, 2001.3. (in Japanese)

栗田治：多角形領域で一様に分布する点から固定点への直線距離の平均值 と 2 次の積率一平均直線距離の等高線の描画法, GIS-理論と応用, 地理情 報システム学会, Vol.9, No.1, pp.29-37, 2001.3.

5) Kurita, O.: Approximation Theory for the Moments of Inter-Regional Euclidean Distance, Journal of the City Planning Institute of Japan, Vol.51, No.3, pp.915-922, 2016.10. (in Japanese)

栗田治: 領域間直線距離の積率近似理論, 日本都市計画学会都市計画論文 集, Vol.51, No.3, pp.915-922, 2016.10.

6) Budzier, H. and Gerlach, G.: Thermal Infrared Sensors: Theory, Optimisation and Practice, Wiley, pp.295-298, 2011.

注

注 1）5章では，「ビジビリティ＝立体角」と考える。一方でそうではなく， <心理的な感覚量は物理的な刺激量の対数に比例して知覚される>という ヴェーバー・フェヒナーの法則を当てはめ, 「ビジビリティ $=\log$ 立体角」 と考えることもできよう。さらにこれを一般化して，＜刺激量が増加する と感覚量も増加するが，その増分は緩やかになる>という定性的な法則に 基づき，「ビジビリティ = 立体角 ${ }^{q}(0<q \leq 1) 」$ と考えることも自然であろ う。なお「 $\log$ 立体角」は，本質的には「立体角」の $q \rightarrow 0$ とした特殊ケー スにすぎない。それは, $1 / q\left(\right.$ 立体角 $\left.^{q}-1\right) \rightarrow \log$ 立体角 $(q \rightarrow 0)$ になることか ら理解できる。

この「ビジビリティ＝立体角」という一般化された立式も，本論の範疇 にある。なぜなら, 後ほど導入するエリアビジビリティの幕指数 $p$ の解釈 を変えることで，この一般化に対応できるからである。具体的には，非公 平性パラメータとして $p$ を導入するが，そうではなく，「 $p$ は非公平性と $q$ の積」だと読み替えればよい。

さらにいうと，「ビジビリティ＝立体角」を認めなくとも，5章以外の 論展開にはおおよそ支障はない。なぜなら，5.3.の計算結果から，

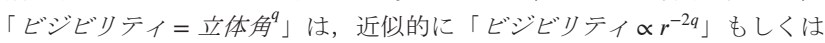

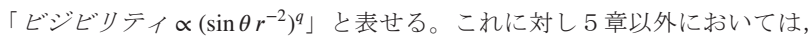

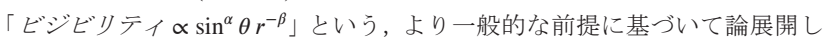
ているからである。

注 2）まず新たな変数 $t(>0)$ を導入し, $t=1 / r$ とおいて変数変換し, 立体角 $\Omega$ を $t$ の関数と考える。すると $t \rightarrow+0$ の近似誤差はゼロであるべきで, $t \rightarrow$ $\infty$ での誤差は許容できるといえる。この前提から, 立体角 $\Omega$ を $t=0$ のまわ り（ただし $t>0 ）$ でテイラー展開する。具体的には， $\Omega(t)$ の $n(=0,1,2 \ldots)$ 階の導関数について $t \rightarrow+0$ として係数を求めていく。計算過程は煩雑であ るので省略し, 結果のみを下に記す。なお $O$ はランダウの記号である。こ れらは共に 6 次の項まで計算したものだが, 奇数次の項は消去されるので, 
結果的に 3 項しか残っていない。また式を見やすくするために $r=1 / t$ の関 係を用いて変数 $t$ を $r$ に逆変換している。つまり結果的にいわば $\Omega$ を $r=$ ののまわりでテイラー展開したことになっている。これらの 2 次の項まで 残したものが, 式(6)と式(7)である。

$\Omega_{\text {sphere }}=\pi c^{2} r^{-2}+1 / 4 \pi c^{2}\left(c^{2}-4 h^{2}\right) r^{-4}+1 / 8 \pi c^{2}\left(c^{4}-4 c^{2} h^{2}+8 h^{4}\right) r^{-6}+O\left(r^{-8}\right)$

$\Omega_{\text {rectangle }}=a b \sin \theta r^{-2}+1 / 16 a b\left(-2 a^{2}+3 b^{2}-24 h^{2}+5 b^{2} \cos 2 \theta\right) \sin \theta r^{-4}$

$+1 / 6144 a b\left[\left(144 a^{4}+18 b^{4}-120 a^{2} b^{2}+5760 a^{2} h^{2}-1440 b^{2} h^{2}+11520 h^{4}\right) \sin \theta\right.$

$\left.+\left(63 b^{4}-280 a^{2} b^{2}-3360 b^{2} h^{2}\right) \sin 3 \theta+189 b^{4} \sin 5 \theta\right] r^{-6}+O\left(r^{-8}\right)$

注 3) ただし式(10)を代入した式(11)の定積分を, 特殊関数を用いて表すこと は可能である。例えばガウスの超幾何関数 $2 \mathrm{~F} 1(\mathrm{a}, \mathrm{b}, \mathrm{c} ; t)$ を用いると, エリア ビジビリティ $g$ は以下のように表せる :

$$
\begin{aligned}
& g=\frac{d^{-\beta}}{(\beta-2)(1-\epsilon)}\left[2 \mathrm{~F} 1\left(\frac{1}{2}, \frac{\alpha+\beta}{2}, \frac{3}{2} ;-\frac{w^{2}}{4 d^{2}}\right)+\epsilon^{-\beta+1} 2 \mathrm{~F} 1\left(\frac{1}{2}, \frac{\alpha+\beta}{2}, \frac{3}{2} ;-\frac{w^{2}}{4 d^{2} \epsilon^{2}}\right)\right. \\
& \left.+\frac{1}{\beta-1} 2 \mathrm{~F} 1\left(\frac{\beta-1}{2}, \frac{\alpha+\beta}{2}, \frac{\beta+1}{2} ;-\frac{w^{2}}{4 d^{2}}\right)-\frac{\epsilon^{-\beta+1}}{\beta-1} 2 \mathrm{~F} 1\left(\frac{\beta-1}{2}, \frac{\alpha+\beta}{2}, \frac{\beta+1}{2} ;-\frac{w^{2}}{4 d^{2} \epsilon^{2}}\right)\right]
\end{aligned}
$$

注 4) 式(11)を解くための方針を, $p$ の值ごとに以下にまとめる。

$p=-1$ のとき：一般の $\alpha$ と $\beta$ に対しては式(11)の 2 重積分を陽に解けな かった（初等関数で表せなかった）ので, パラメータ $\alpha$ と $\beta$ の特定の 4 パ ターンの組み合わせに対してのみ解いている。なお式を見やすくするため に, $m=\sqrt{ }\left((w / 2)^{\wedge} 2+d^{\wedge} 2\right), n=\sqrt{ }\left((w / 2)^{\wedge} 2+(d \epsilon)^{\wedge} 2\right)$ という 2 変数を導入し ている (共通)。

$p=1$ のとき：一般の $\alpha$ と $\beta$ に対しては式(11)を陽に解けなかったので, 特定の 3 パターンの組み合わせに対して解いている。 $p=1, \alpha=0, \beta=2$ の ときには陽に解けないと思われる。

$p \rightarrow-\infty$ のとき : $g$ がビジビリティの最小值と等しくなることを利用し て計算している。視対象からみて奥の角部 $(x, y)=(w / 2, d)$ もしくは手前の 角部 $(x, y)=(w / 2, d \epsilon)$ においてビジビリティは最小值をとる。

$p \rightarrow \infty$ のとき： $g$ がビジビリティの最大值と等しくなることを利用して 計算している。視対象に最も近い視点 $(x, y)=(0, d \epsilon)$ においてビジビリティ は最大值をとる。

$p \rightarrow 0$ のとき： $g$ がビジビリティの相乗平均と等しくなることを利用し て計算している。 $\left(\prod_{i=1}^{n} v_{i}\right)^{1 / n}=\exp \left(1 / n \sum_{i=1}^{n} \log v_{i}\right)$ の関係を用い, 対数をと ってから積分計算している。結果, 一般の $\alpha$ と $\beta$ において, 式(11)を初等 関数で表すことができる。 


\title{
SHAPE OPTIMIZATION OF ROOMS WITH A VISUAL TARGET TO MAXIMIZE ITS VISIBILITY
}

\author{
Kentaro HONMA ${ }^{* 1}$ and Kotaro IMAI*2 \\ ${ }^{* 1}$ Assoc. Prof., Inst. of Industrial Science, The Univ. of Tokyo, Dr.Eng. \\ ${ }^{*}$ Prof., Inst. of Industrial Science, The Univ. of Tokyo, Dr.Eng.
}

The objective of this paper is to quantify the room shape in terms of visibility of a visual target within the room, thus finally to obtain the optimal room shape. A wide variety of visual targets are envisaged, such as a blackboard within a classroom, a stage in a theater, or a painting in a gallery. Their common point is that they are so important that their visibility impacts the room shape. In order to obtain planning guidelines of various rooms with various visual targets, the visibility theory is developed in both a unified and a deductive way. In concrete terms, (i) A reasonable function for expressing "point-visibility" is proposed from an arbitrary viewpoint. The proposed formula not only is understandable intuitively and operational, but represents generalization of approximation equation for the solid angle of the visual target. (ii) Next, a reasonable method of aggregating point-visibility is proposed. Therefore "area-visibility" as a value for evaluating the space as a whole is derived, doubly integrating the $p$-th power of point-visibility. Areavisibility can be used to evaluate both classrooms that need equality among students by focusing bad view areas, and galleries where the visitor can determine the viewing position by focusing good view areas. (iii) Finally, the optimal room shape is derived in which area-visibility is maximized. Here, we obtain the optimal aspect ratio of a rectangular plan room where the visual target is on one wall.

Through the process described above, this paper is successful in clearly describing area-visibility as the formula containing three parameters and obtaining the relationship between these values and optimal room shapes. These three consist of the two parameters derived from the point-visibility function (negative impact $\alpha$ when viewing the target at an angle, and negative impact $b$ when viewing the target far away) , and one parameter introduced when aggregating point-visibility (degree of inequality $p$ in the visibility distribution)

This means that " $\alpha$ and $B$ representing human eyesight" and " $p$ depending on rooms' usage" can be directly linked to an "evaluation value of room shape known as area-visibility", and thus the "optimal shape of the room". In other words, once the preconditions are determined, we can obtain information immediately that is useful for planning and design. In consequence, this is considered to be valid knowledge that allows the visibility evaluation that previously was carried out based on experience to be performed objectively. 